\title{
DIRECTIONS TO DEVELOP MANAGERIAL COMPETENCE IN MANAGERS OF DIFFERENT TYPES
}

\author{
Viktoriia Luhova $^{1}$, Denys Serikov², Yaroslava Liutviieva ${ }^{3}$, Tetiana Serikova $^{4}$, Viktoriia Kovalova ${ }^{5}$ \\ ${ }^{I}$ Assoc. Prof., PhD (Econ.) Simon Kuznets Kharkiv National University of Economics. Nauky Ave. $9 a .61166$ Kharkiv, \\ Ukraine. Phone: +38 (066) 3622223. Email: viktoriia.luhova@hneu.net \\ ${ }^{2}$ Lecturer, PhD (Econ.) Simon Kuznets Kharkiv National University of Economics. Nauky Ave. $9 a .61166$ Kharkiv, \\ Ukraine. Email: denys.serikov@hneu.net \\ ${ }^{3}$ Senior lecturer, Simon Kuznets Kharkiv National University of Economics. Nauky Ave. 9a. 61166 Kharkiv, Ukraine. \\ Email: yaroslava.liutviieva@hneu.net \\ ${ }^{4}$ Assoc. Prof., PhD (Econ.) Simon Kuznets Kharkiv National University of Economics. Nauky Ave. 9a. 61166 Kharkiv, \\ Ukraine.Email: serikovatatiana2018@gmail.com \\ ${ }^{5}$ Assoc. Prof., PhD (Econ.) National University of Pharmacy, 53, Pushkinska str, 61002, Kharkiv, Ukraine. Email: \\ vikakova04@gmail.com
}

Received 1105 2021; Accepted 12052021

\begin{abstract}
The aim of the article is to determine the directions to improve the managerial competence of enterprise managers, depending on the level of development of the personal and functional component of their competence. To achieve this goal, the following research methods were used: generalization, comparison, analysis and synthesis, questionnaire method, cluster analysis and graphical method. The essence of the concept "managerial competence of a manager" was clarified and the components of competence were identified. In order to concretize and generalize the tools to develop managerial competence of managers, we have developed their typology and singled out four types: self-advanced, temporarily competent, temporarily incompetent, and incompetent. For the empirical testing of the theoretical statements a cluster analysis was made on the basis of the data gathered in the process of the self-assessment of the managers' competence, and the types of managers depending on the development of their functional and personal components were identified. The recommendations to develop managerial competence are given for each type of managers.
\end{abstract}

Keywords: professionalization, managerial competence, personal component of competence, functional component of competence, manager, type of manager.

JEL Codes: O15, L84.

\section{Introduction}

The professionalization of management, which was discussed at the end of the twentieth century, is aimed at improving the quality and efficiency of management, primarily through professional training of managers and ensuring a high level of managerial competence. In Ukraine, the processes of formation of the information society are taking place, which ensure the development of information economy and require the updating of management models. We accept the view of Chernichko (2015) that in order to bring domestic economic processes closer to European standards, it is becoming increasingly important to solve the problem of radically improving efficiency of management activities. To solve it, it is necessary to use a wide range of existing resources and among which the managerial professionalism has a significant potential. Modern Ukrainian

Copyright (C 2021 Author(s), published by Vytautas Magnus University. This is an open access article distributed under the terms of the Creative Commons Attribution Non-Commercial 4.0 (CC BY-NC 4.0) license, which permits unrestricted use, distribution, and reproduction in any medium provided the original author and source are credited. The material cannot be used for commercial purposes. 
enterprises operate in extremely unstable conditions of the external environment, which lead to a complication of in-house relations and require from managers to make innovative and creative decisions as well as be flexible. Modern managers are increasingly perceived as leaders and innovators, who are expected to have in-depth knowledge in various fields, and this knowledge has to be constantly advanced and updated. Ivanova (2006) noted that managerial staff are owners of intellectual capital; their skills and competencies are key elements of any successful business and directly affect its performance and market attractiveness. Furthermore, that today's managers are system-oriented professionals who do today what others will only think of doing tomorrow. Komendant and Mikhailov (2001) point out that management as an art is associated with the manager's ability to solve managerial problems in a unique, original, talented way, with the least waste of energy and resources but with high efficiency, which to a large extent depends on the personal qualities and characteristics of the manager and the level of his or her professional training as a manager.

Managerial competence of a manager is a complex professional and personal formation, which is actualized in the process of managerial activity, provides readiness and ability to perform it at the regulatory level and includes knowledge, skills, personal qualities and abilities, values, motives and evaluations. In the conditions of permanent changes managerial competence has to be improved at a faster pace, which increases the relevance of such a problem as motivation of managers' self-development and development of managerial competence.

The issues of professional competence and professional activity were considered in the works of Zakharchenko and Medvedev (2012), Komendant and Mikhailov (2001), Litovchenko and Lugova (2014). Managerial competence, its formation and development were studied in the works of Voloshka (2011), Lutsky (2012), May (1999), Winterton, J., Winterton, R (1999), Chong E. (2011). The problem of forming managerial competence of managers was the subject of research by Olifira
(2011), Carmeli. (2006), Kalinska, Sushentseva and Ivasyk (2020).

The purpose of this article is to identify areas for improving the managerial competence of managers who work at different types of enterprises, depending on the level of development of the personal and functional component of their competence.

Research methods: methods of generalization, comparison, analysis and synthesis to determine the essence of categories and concepts of the research; questionnaire survey, for self-assessment of functional and personal components of managerial competence of enterprise managers; cluster analysis to group managers by the level of development of personal and functional components of managerial competence; graphic to illustrate empirical data and schematic representation of the basic theoretical and practical statements. Microsoft Excel and Statistica 10.0 application software packages were used to fulfil the tasks.

\section{Research results and their explanation}

To consider the essence of managerial competence we take into account the peculiarities of this type of activity. Voloshko (2011) understands managerial competence of a manager as an integrative personality trait, including managerial position, managerial knowledge and skills, significant for effective management of personality trait, which reflects his or her willingness and ability to engage in professional activities effectively, solving organizational and managerial tasks in the social sphere.

Zakharchenko and Medvedeva (2012) consider managerial competence as a professional personality trait that integrates professional and managerial knowledge, skills and abilities developed on its basis and realised in professional activities that allow managers to act independently and effectively.

Shamova (2001) believes that managerial competence is knowledge, and the main ability is to use knowledge in the process of management.

Olifira (2010) concluded that professional management competence in modern science is considered as a set of 
personal qualities and abilities of the management entity, its professional knowledge, competence and experience, which allow to participate in making effective decisions and managing a team, subordinates, staff and organization successfully.

Lutsky (2012) notes that managerial competence is a complex individualprofessional formation that integrates professional theoretical knowledge, practical abilities and skills, professional and personal values and qualities, ensures qualified managerial activity and deliberates choice of behavioural patterns.

Critical analysis and synthesis of scientific approaches to the interpretation of the concept "managerial competence of a manager" allow to clarify its essence as a complex professional and personal formation, which is actualized in the process of managerial activity, provides readiness and ability to perform it at the normative level and includes knowledge, skills, personal qualities and abilities, values, motives and evaluation. In the proposed definition, the emphasis is made on substantiating the key role of a personality, his or her readiness and ability to develop the managerial functions. Thus, analysing managerial competence of manager, it is necessary to distinguish its two interrelated components: functional forming a set of knowledge, skills and abilities to solve management tasks, and personal forming a set of needs, interests, motives, attitudes, values and goals of managerial activity, the ability of adequate self-assessment as a personality, professional and the managerial entity.

In order to solve the tasks of this study, it is necessary to develop guidelines for the development of managerial competence; it is advisable to conduct a typology of managers depending on the level of development of functional and personal competence components. Thus, we can identify four types of managers (table 1).

\section{Table 1. Typology of managers according to the development of competence components}

(Developed by the authors)

\begin{tabular}{|l|l|}
\hline \multicolumn{1}{|c|}{ Type of a manager } & \multicolumn{1}{c|}{ Characteristic } \\
\hline Self-advanced & $\begin{array}{l}\text { Sufficient level of knowledge, skills and abilities of a manager to perform managerial } \\
\text { functions which are combined with a high level of self-development motivation, efforts to } \\
\text { maximize their abilities and qualifications, and adequate self-assessment }\end{array}$ \\
\hline Temporarily competent & $\begin{array}{l}\text { Sufficient level of knowledge, skills and ability of adequate self-assessment to perform } \\
\text { managerial functions, but lack of desire for self-development, increase of professionalism, } \\
\text { inadequate self-esteem, mismatch between socio-psychological qualities and abilities of a } \\
\text { managerial position }\end{array}$ \\
\hline incompetent & $\begin{array}{l}\text { Insufficient level of knowledge, skills and abilities of a manager to perform managerial } \\
\text { functions which are combined with a high level of self-development motivation, efforts to } \\
\text { maximize their abilities and qualifications, and adequate self-assessment }\end{array}$ \\
\hline Incompetent & $\begin{array}{l}\text { Insufficient level of competence of a manager as a whole: lack of desire for self-development, } \\
\text { increase the level of professionalism, inadequate self-assessment, mismatch between socio- } \\
\text { psychological qualities and abilities of a managerial position }\end{array}$ \\
\hline
\end{tabular}

These theoretical typologies need to be empirically tested in specific studies, so in order to identify the types of managers depending on the development of their functional and personality components, we conducted a cluster analysis based on the data collected in the process of competence selfassessment by enterprise managers.

The use of the cluster analysis method is primarily driven by the convenience of

Copyright () 2021 Author(s), published by Vytautas Magnus University. This is an open access article distributed under the terms of the Creative Commons Attribution Non-Commercial 4.0 (CC BY-NC 4.0) license, which permits unrestricted use, distribution, and reproduction in any medium provided the original author and source are credited. The material cannot be used for commercial purposes. 
dividing the set of objects under study into homogeneous groups according to the selected characteristics. The typology of managers according to the development of functional and personality components was carried out by using the package of statistical processing information "STATISTICA", version 10.0.
Based on the clustering of data resulting from self-assessment of fifty managers of Ukrainian enterprises, the k-means method revealed that there are different groups of managers who face problems of uneven development of their own competence components (figure 1).

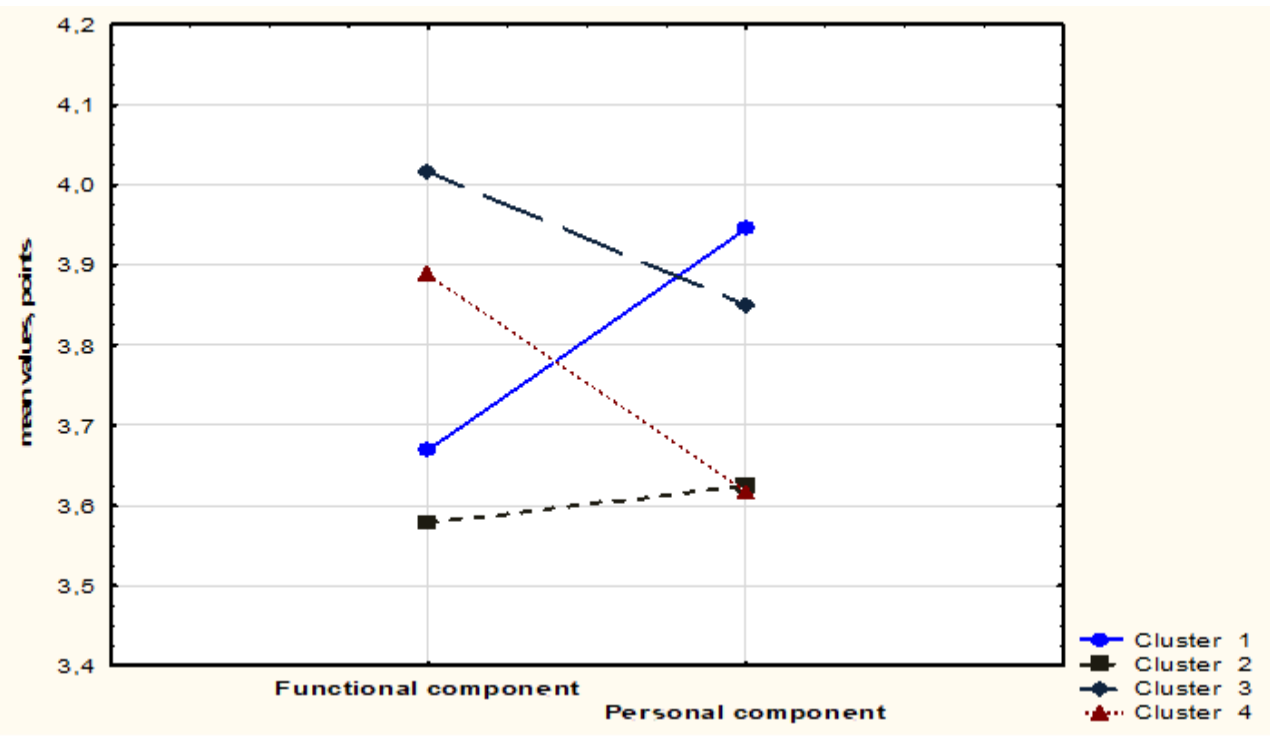

Figure1. The results of clustering business managers in competence development by $k$ means method (Developed by the authors)

In figure 1 , we can clearly see separated clusters of managers who admit to having problems in the development of the competence components. It is worth noting that using the agglomerative method of complete-linkage clustering and Ward's method showed the same result as the k-means method. This fact proves the validity of the chosen method (figure 2).
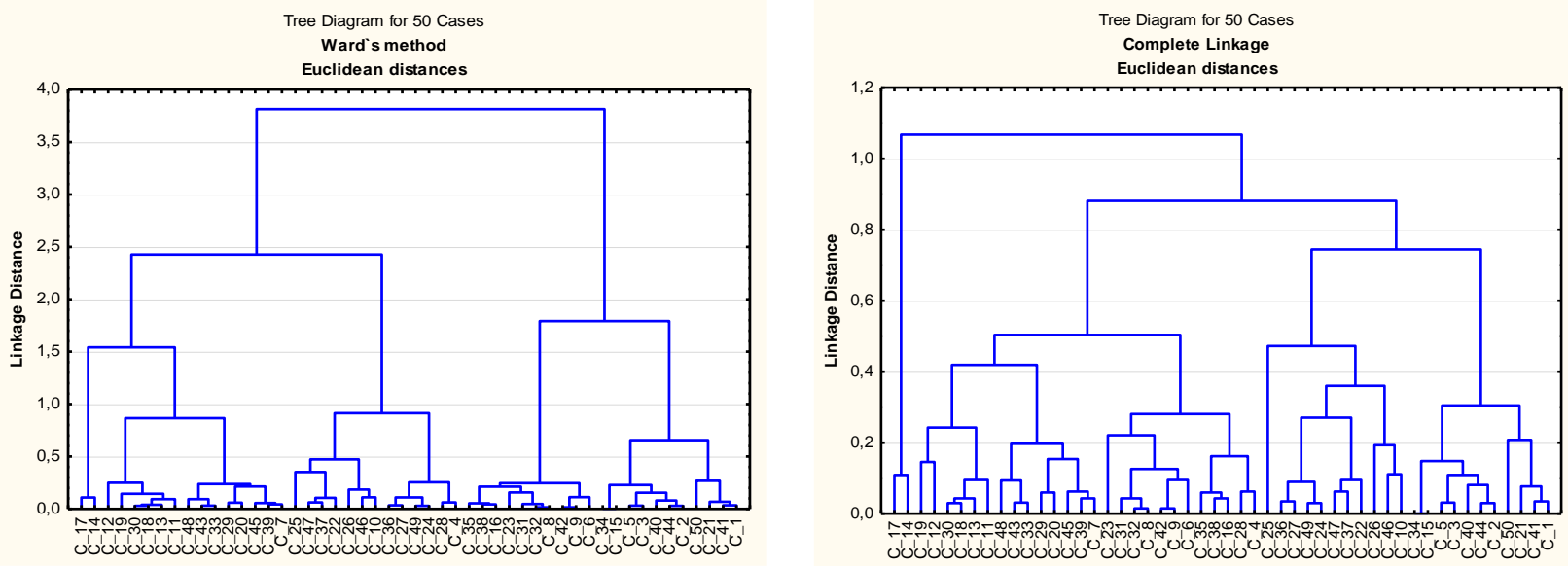

Figure 2. The results of clustering business managers in competence development by Ward's method and complete-linkage clustering

(Developed by the authors) 
Management Theory and Studies for Rural Business and Infrastructure Development

eISSN 2345-0355. 2021. Vol. 43. No. 2: 269 - 275

Article DOI: https://doi.org/10.15544/mts.2021.23

The analysis of variance showed that the findings are a basis for decision-making, as the values of inter-group variance are high and the values of intra-group variance are low, indicating a qualitative distribution of business managers into groups (figure 3 ).

\begin{tabular}{|c|c|c|c|c|c|c|}
\hline \multirow[b]{2}{*}{ Variable } & \multicolumn{6}{|c|}{ Analysis of Variance (Spreadsheet1) } \\
\hline & \begin{tabular}{|c|} 
Between \\
SS
\end{tabular} & df & $\begin{array}{c}\text { Within } \\
\text { SS }\end{array}$ & df & $\mathrm{F}$ & $\begin{array}{c}\text { signif. } \\
\text { p }\end{array}$ \\
\hline Funktional component & 1,577681 & 3 & 0,808960 & 46 & 29,90397 & 0,000000 \\
\hline Personal component & 1,000337 & 3 & 0,448538 & 46 & 34,19668 & 0,000000 \\
\hline
\end{tabular}

Figure 3. The results of the analysis of variance

(Developed by the authors)

So, according to the clustering results, the first cluster includes managers who believe that their personality component is quite high, but their functional component is low, it means that they are temporarily incompetent (24\% of managers). The second cluster includes managers who has not rated their functional and personality competence as quite enough (28\% of managers). The third cluster includes self-advanced managers, who believe that all components of their competence are developed at a sufficiently high level (26\% of managers). The fourth cluster includes managers who believe that their functional component is very well developed, while their personality component is at a low level of development, it means that they are temporarily competent (22\% of managers). A negative tendency that can be observed in most of the studied enterprises is the significant number of managers of the temporarily competent type. This indicates that managers lack certain socio-psychological qualities needed for effective managerial activity and a low level of managers' motivation, including selfdevelopment, which leads to a lack of interest in improving their competence.

Table 2. Directions to develop the managerial competence in managers of different types (Developed by the authors)

\begin{tabular}{|c|c|c|}
\hline Type of a manager & Directions to develop competence & Outcome \\
\hline Self-advanced & $\begin{array}{l}\text { Maintaining a sufficient level of motivation for self-development by using } \\
\text { educational methods and self-management }\end{array}$ & \multirow{4}{*}{ 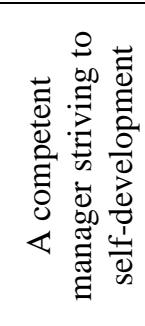 } \\
\hline $\begin{array}{l}\text { Temporarily } \\
\text { competent }\end{array}$ & $\begin{array}{l}\text { Creating motivation for self-development by using administrative, economic and } \\
\text { socio-psychological methods }\end{array}$ & \\
\hline $\begin{array}{l}\text { Temporarily } \\
\text { incompetent }\end{array}$ & $\begin{array}{l}\text { Developing competence by constructing an individual managerial competence } \\
\text { development programme }\end{array}$ & \\
\hline Incompetent & $\begin{array}{l}\text { Creating motivation for self-development by using administrative, economic and socio- } \\
\text { psychological methods and an individual competence development programme }\end{array}$ & \\
\hline
\end{tabular}

Thus, it should be noted the advisability of applying the proposed method in order to identify the type of a manager and provide guidelines to develop managerial competence of specific groups of managers.

Copyright (C) 2021 Author(s), published by Vytautas Magnus University. This is an open access article distributed under the terms of the Creative Commons Attribution Non-Commercial 4.0 (CC BY-NC 4.0) license, which permits unrestricted use, distribution, and reproduction in any medium provided the original author and source are credited. The material cannot be used for commercial purposes. 


\section{Conclusions}

The diagnostics of managerial competence of managers based on its components enabled us to determine that one of the main problems is uneven development of functional and personal components of managers' competence, which allows us to carry out their typology in order to develop guidelines for a specific type of manager. In view of this the following types of managers were identified using the method of theoretical typology: self-advanced, temporarily competent, temporarily incompetent, incompetent. Cluster analysis usage proved the hypothesis that there are different types of managers in the enterprises, which differ in the level of development of personal and functional competence components.

The tools to develop the managerial competence of different types of managers are presented. Self-advanced managers with a high level of functional and personal competence need to maintain a high level of knowledge, skills and abilities by providing them with opportunities for self-learning and selfdevelopment in accordance with needs and a high level of self-development motivation by using educational and self-management methods. Temporarily incompetent managers need to focus on the development of the functional component of competence, and require the acquisition of knowledge, skills and abilities in accordance with the needs of managers and the requirements of the workplace by creating a tailored training programme. Temporarily competent managers lack motivation for self-development and require the use of administrative, economic and socio-psychological methods to motivate them. Incompetent managers need the greatest contribution to the process of acquiring the knowledge, skills and abilities, require to create a tailored learning programme and considerable effort to motivate selfdevelopment by using administrative, economic and socio-psychological methods.

\section{References}

Carmeli, A. (2006) The managerial skills of the top management team and the performance of municipal organisations, Local Government Studies, Vol. 32, is. 2, 153-176

Chernychko T. V. (2015). Professionalization as a process of improving managerial efficiency in the context of European standards. Scientific Bulletin of Kherson State University. Series : Economic Sciences. Edition. 12. Vol. 3: 5356. Retrieved from http://www.ej.kherson.ua/journal/economic_12/120.pdf [10.05.2021].

Chong E. (2013). Managerial Competencies and Career Advancement: A Comparative Study of Managers in Two Countries. Journal of Business Research. Vol. 66: 345-353

Ivanova I. V. (2006). Professionalization of management: monograph. - Kyiv: KNTEU. 695 p.

Kalins'ka O., Sushentsev O., Ivasyk I. (2020). The essence and structure of the basic concepts of managerial competence of the head of a professional education institution. Current issues in the humanities. Edition 33, Vol. 1: 360367. Retrieved from http://www.aphn-journal.in.ua/archive/33_2020/part_1/56.pdf [10.05.2021].

Komendant A. G., Mikhaylov G. S. (2001). Psychological problems of a manager's professional activity. Moscow : Public education. 192 p.

Luts'kyy O. L. (2012). Methodological recommendations to academic staff for the development of managerial competence of officers at State Border Protection Service. Collection of scientific works of the Khmelnytsky Institute of Social Technologies of the University "Ukraine". № 5: 131-134. Retrieved from Retrieved from http://nbuv.gov.ua/UJRN/Znpkhist_2012_5_30 [10.05.2021].

Lytovchenko I.V., Luhova V.M. (2014) Ensuring the development of professional competence of management staff on the basis of program-oriented approach. Economic Journal-XXI. № 9-10 (2): 56-59. Retrieved from http://soskin.info/userfiles/file/2014/9-10_2014/2/Lugova_Litovchenko.pdf [10.05.2021].

Maralov V. G. (2004). The basics of self-knowledge and self-development. - Moscow: Academy, 256 p.

May A. (1999). Developing management competencies for fast-changing organisations, Career Development International, Vol. 4 No. 6: 336-339. Retrieved from https://doi.org/10.1108/13620439910288022 [10.05.2021]. 
Management Theory and Studies for Rural Business and Infrastructure Development

Olifira L. (2010). The problem of forming the professional management competence of directors of educational institutions in psychological and pedagogical research. Theory and Methodology of Educational Management. № 3. Retrieved from http://tme.umo.edu.ua/docs/3/10olippr.pdf [10.05.2021].

Shamova T. I., Tret'yakov P. I., Kapustin N. P. (2001) Management of education systems. Moscow : VLADOS. $320 \mathrm{p}$.

Voloshka V. (2011). Implementing organizational and pedagogical conditions of formation and development of managerial competence of manager in a social sphere. Humanisation of the educational process. Special edition 7: 5768.

Winterton, J., Winterton, R. (1999). Developing Managerial Competence. - Routledge. 324 p.

Zakharchenko L. A., Medvedeva G. B. (2012). Formation and development of professional competencies of the manager in the system of university and postgraduate training. Bulletin of Brest State Technical University. № 6: 61-64. Retrieved from https://www.bstu.by/uploads/vestnik/6/2012_6_zaxarchenko_l.a.,_medvedeva_g.b._formirovanie_i_razvitie_profession alnyx_kompetencij_upravlenca-menedzhera_v_sisteme_vuzovskoj_i_poslevuzovskoj_podgotovki.pdf [10.05.2021].

Copyright (C 2021 Author(s), published by Vytautas Magnus University. This is an open access article distributed under the terms of the Creative Commons Attribution Non-Commercial 4.0 (CC BY-NC 4.0) license, which permits unrestricted use, distribution, and reproduction in any medium provided the original author and source are credited. The material cannot be used for commercial purposes. 